\title{
Comprehensive care from the perspective of nurses: an ecosystem approach
}

\author{
Cuidado integral na ótica de enfermeiros: uma abordagem ecossistêmica \\ Atención integral desde la perspectiva de enfermeras: un enfoque ecosistémico
}

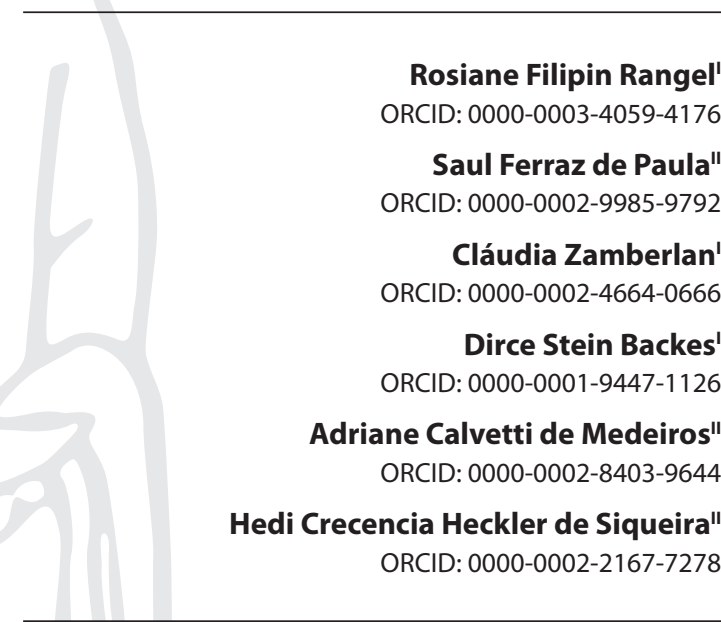

'Universidade Franciscana. Santa Maria, Rio Grande do Sul, Brazil.

"Universidade Federal do Rio Grande. Rio Grande, Rio Grande do Sul, Brazil.

How to cite this article: Rangel RF, Paula SF, Zamberlan C, Backes DS Medeiros AC, Siqueira HCH. Comprehensive care from the perspective of nurses: an ecosystem approach. Rev Bras Enferm. 2020;73(Suppl 6):e20190781. doi: http://dx.doi.org/10.1590/0034-7167-2019-0781

\section{Corresponding author: \\ Rosiane Filipin Rangel \\ E-mail: rosianerangel@yahoo.com.br

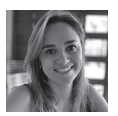

EDITOR IN CHIEF: Antonio José de Almeida Filho ASSOCIATE EDITOR: Priscilla Valladares Broca

Submission: 02-10-2019

Approval: 07-27-2020

\section{ABSTRACT}

Objectives: to verify nurses' perceptions about comprehensive care to human beings from the ecosystem perspective, with Therapeutic Touch use. Methods: an exploratorydescriptive, qualitative study, conducted with 11 nurses who use/used Therapeutic Touch in daily work. Data were collected through online semi-structured interviews and submitted to discursive textual analysis. The ecosystem framework was used. Results: participants talked about the theme in a polysemic way, but understand that comprehensive care is associated with nursing professionals and intrinsic in their being and doing, considering the philosophical theoretical bases of nursing, which aim at the comprehensiveness of being. Final Considerations: Therapeutic Touch was considered as a way to achieve comprehensive care caring to human being ins. The objective of the study was achieved; however, it is understood the need for other research to advance this knowledge and enable innovations in professional practice of nurses.

Descriptors: Nursing Care; Therapeutic Touch; Complementary Therapies; Nursing; Ecosystem.

\section{RESUMO}

Objetivos: averiguar a percepção dos enfermeiros acerca do cuidado integral ao ser humano na perspectiva ecossistêmica, a partir da utilização do Toque Terapêutico. Métodos: estudo exploratório-descritivo, qualitativo, realizado com 11 enfermeiros que utilizam/utilizaram o Toque Terapêutico no cotidiano de trabalho. Os dados foram coletados por meio da técnica de entrevista semiestruturada e submetidos à Análise Textual Discursiva. Utilizou-se o referencial ecossistêmico. Resultados: os participantes discorreram acerca da temática de uma maneira polissêmica, mas entendem que o cuidado integral é inerente ao profissional enfermeiro, pois está intrínseco no seu ser e fazer, considerando as bases teórico filosóficas da profissão, que visam à integralidade do ser. Considerações Finais: o Toque Terapêutico foi considerado como uma forma de cuidar o ser humano na sua integralidade. $O$ objetivo do estudo foi alcançado, contudo entende-se a necessidade de outras pesquisas que avancem nesse conhecimento e possibilite inovações nas práticas profissionais do enfermeiro.

Descritores: Cuidados de Enfermagem; Toque Terapêutico; Terapias Complementares; Enfermagem; Ecossistema.

\section{RESUMEN}

Objetivos: conocer la percepción de los enfermeros sobre la atención integral al ser humano desde una perspectiva ecosistémica, a partir del uso del Tacto Terapéutico. Métodos: estudio exploratorio-descriptivo, cualitativo realizado con 11 enfermeras que usan/usaron Tacto Terapéutico en su trabajo diario. Los datos fueron recolectados mediante la técnica de entrevista semiestructurada y sometidos a Análisis Textual Discursivo. Se utilizó la referencia del ecosistema. Resultados: los participantes discutieron el tema de manera polisémica, pero entienden que el cuidado integral es inherente al profesional enfermero, ya que es intrínseco a su ser y hacer, considerando las bases teóricas y filosóficas de la profesión, que apuntan a la integralidad del ser. Consideraciones Finales: se consideró el Tacto Terapéutico como una forma de cuidar al ser humano en su totalidad. El objetivo del estudio se logró, sin embargo, se entiende la necesidad de realizar más investigaciones que avancen en este conocimiento y posibiliten innovaciones en las prácticas profesionales de las enfermeras. Descriptores: Atención de Enfermería; Tacto Terapéutico; Terapias Complementarias; Enfermería; Ecosistema. 


\section{INTRODUCTION}

Discussions about care in nursing are a continuous practice, as this is the main focus of nursing. However, it is observed that there is a need to direct these reflections to an enlarged view, understanding what is recommended by the Unified Health System (SUS - Sistema Único de Saúde) in its guidelines and public policies as well as the complexity of human beings.

This context allows us to think about comprehensive care, understood as a practice that meets the various dimensions of human beings, considered a complex phenomenon that aims to promote it as a singular and multidimensional being, not happening only through the action of a subject, but through a care network that must go beyond the visible needs ${ }^{(1-2)}$.

In this regard, it is understood that, for nursing, it is necessary to systematize and manage care in the different settings of health care $^{(2)}$. In the professional practices, the biomedical model prevalence is still observed, which reinforces the super-specializations, emphasizes the care in specific problems centered on professionals and disregards the needs of people in their uniqueness and collectivity ${ }^{(3)}$.

The context presented is a challenge for nursing. Nursing needs to be sensitized to a new practice based on theoretical philosophical references that support the understanding of human beings in their multidimensionality and on new therapeutic bases that refer to comprehensive care $^{(3)}$. From these gaps that guide the fragmentation of nursing care, we chose, in this construct, to use the ecosystem framework. Ecosystem refers to space, home, place that human beings live and develop, constituted by the totality of elements that are part of that space, whether they are biotic (social) and abiotic (physical) elements, which interact and carry out exchanges among themselves ${ }^{(4)}$.

From this perspective, comprehensive care must be developed from the elements that make up the ecosystem where human beings are inserted as well as the relationships that are established during the development of this care, i.e., a direction that goes beyond the biological dimension of human beings. Thus, aiming at a continuous, humanized and comprehensive health care, in order to contribute to the resolution and to encourage new alternatives that cooperate with a sustainable development of communities and encourage social control/participation in Brazil, the Ministry of Health approved in 2006 the Brazilian National Policy of Integrative and Complementary Practices (PNPIC - Política Nacional de Práticas Integrativas e Complementares) in SUS ${ }^{(5)}$. Therefore, it is worth noting that Therapeutic Touch directs and limits the investigation of this study, which has as its main focus the comprehensive care developed by nurses.

Integrative and Complementary Practices (PICS - Práticas Integrativas e Complementares) in nursing can contribute in a unique way. They are natural therapies that aim to care for human beings through a comprehensive vision. PICS are opposed to the technicist and biomedical model, in which care is fragmented through drug methods and interventions, sometimes unnecessary, focused only on the biological dimension ${ }^{(6)}$.

Therapeutic Touch (TT) is a laying on of hands technique that aims to harmonize with Human Energy Field (HEF), proposed by American nurse Dolores Krieger, together with therapist Dora Kunz, in the 1970s, and which has been arousing interest of researchers for their significance in caring for human beings. Originated from oriental healing models, it is based on an comprehensive and scientific view that includes the presence of energy fields surrounding organisms $s^{(7)}$. Therefore, research that reflects on TT in comprehensive care for human beings must be carried out. Therefore, it is necessary to encourage scientific reflections aiming at a greater understanding of the contributions of this knowledge ${ }^{(8)}$.

It is worth mentioning that laying on of hands practices were not initially available in the PNPIC. However, these were included in the year 2018 through Ordinance 702, which amended Consolidation Ordinance 2 of 2017, in which, in this modality, only Reiki was foreseen ${ }^{(9)}$.

\section{OBJECTIVES}

To verify nurses' perceptions about comprehensive care to human beings from the ecosystem perspective, with TT use.

\section{METHODS}

\section{Ethical aspects}

To meet the ethical criteria, the project was sent to the Research Ethics Committee in the Field of Health (CEPAS-Comitê de Ética em Pesquisa na Área da Saúde) of Universidade Federal do Rio Grande (FURG), in order to meet the requirements of Resolution 466/12 of the Brazilian National Ethics Commission in Research/Ministry of Health (CONEP (Comissão Nacional de Ética em Pesquisa/Ministério da Saúde)/MoH) on research involving human beings ${ }^{(10)}$. In order to maintain participant anonymity, they were identified, throughout the text, by letter " $\mathrm{N}$ ", followed by an ordinal number.

\section{Theoretical framework}

We have used the ecosystem framework, which allows promoting an integrative, interrelational, circular, dynamic thinking, considering the interactive possibilities between the elements of a given environment. Human beings, in the ecosystemic view, are understood as a multidimensional system, constituted by biological, psychological, social and spiritual dimensions. They interact with each other, are interdependent, interconnected and influence each other, maintaining the dynamics of life $e^{(4,11)}$. Thus, using this philosophical theoretical framework is suitable for addressing comprehensive care developed by nurses and investigated through TT practice.

\section{Type of study}

This is a qualitative, descriptive and exploratory research.

\section{Participant selection, collection and organization of data}

The data were collected through a semi-structured interview, which explored nurses' perceptions about the possibility of achieving comprehensive care for human beings, from an ecosystem perspective, using TT. 
Eleven nurses who use/used TT in their daily work in different health settings participated in the study. For the selection of participants, the Snowball technique was used. Thus, to find the first study participants, a search was carried out in the CAPES thesis database in January 2018, carrying out a survey of the theses that used the theme "Therapeutic Touch", by reading abstracts.

From this stage, a bank with the name of the researchers was built, looking for the curriculum in the Curriculum Lattes platform in order to obtain the professional address for the first contact. In this search, three theses were found, one from 1999 and two from 2011. From this search, the seed of the study was identified, i.e., the first participant, which indicated the next ones that were called fruits/children.

First contact was made via e-mail with the author of the thesis with the oldest date found, inviting her to participate in the study, expressing interest, but did not return to e-mails. Thus, we waited for a month, making a weekly contact to reinforce the need to schedule the interview. As there was no return, contact was made with the author of the second oldest thesis.

The author returned to the email, but did not accept to participate in the research. Thus, contact was made with the author of the third oldest thesis, via e-mail, who accepted to participate in this research. This researcher was the seed that later indicated the next participants, i.e., the six fruits/children.

Then, via e-mail, according to the seed's preference, the Informed Consent Form (ICF) and the interview was scheduled. Afterwards, contact was made with the six fruits/children via e-mail and/or telephone. As previously mentioned, they were invited to participate in the research, signed the ICF and the interview was scheduled. As they answered the interviews, they were also invited to indicate the next fruits/children. Thus, four more fruits/ children were obtained. The interviews were conducted between the months of February and July 2018, through video calling via WhatsApp, Skype and telephone, and participants chose the way to respond as they considered relevant. It should be noted that this conduct was adopted according to the geographical distances of participants found in the search as well as their availability.

The inclusion criteria for the seed were: a nurse who uses TT, who defended a thesis using TT and who has a lattes curriculum with a professional address. The exclusion criteria were: those removed from professional activities due to health problems, maternity leave, retirement. Inclusion criteria for children/fruits: nurses who use/used TT in their daily professional work in different health settings. Exclusion criteria were: nurses who, during the data collection period, were away from professional activities due to health problems, maternity leave, among other reasons. Data collection was completed at a time when participants no longer had any indication of fruit/children.

\section{Analysis of data}

The data were analyzed and interpreted according to Discursive Textual Analysis. Discursive Textual Analysis works with meanings constructed from the set of analyzed texts, the corpus, which was outlined by the transcripts of the interviews conducted. Discursive Textual Analysis, although composed of rationalized and to some extent planned elements, as a whole constitutes a self-organized process from which new understandings emerge, starting from a sequence, with unitarization, the establishment of relationships and communication ${ }^{(12)}$.

In unitarization, texts were examined thoroughly, fragmenting them in order to reach units of meaning. This step was carried out with intensity and depth. In categorization, similar units of meaning were assembled, which generated levels of analysis categories. In communication, the understandings reached from the two previous focuses were expressed. It was constituted, in the last element of the proposed analysis cycle, resulting in metatexts, which were constituted of description and interpretation, representing the whole, a way of theorizing about the investigated phenomena ${ }^{(12)}$.

\section{RESULTS}

Of the 11 survey participants, 10 were female and one male, aged between 31 and 61 years. As for performance, five were exclusively teachers, two worked in assistance, three performed both activities concurrently and one was a coaching nurse. Of these, two had specialization, four held master's degrees and five held a PhD. As for the time working with TT, it varied from nine months to 25 years. Seven lived in the state of São Paulo and four in the state of Mato Grosso do Sul.

From data analysis, six categories emerged, and in this article, the category entitled "Comprehensive care from nurses' perspective' from TT: a polysemic understanding" will be presented.

\section{Comprehensive care from nurses' perspective' from TT: a polysemic understanding}

Participants, through their studies/experiences with TT, understand that comprehensive care is inherent to nurses, is intrinsic in their being and doing, considering the philosophical theoretical bases of the profession that aim at the comprehensiveness of human beings.

[...] I believe that it is the nurses 'own view in making the model [...] and the world view of nursing are holistic [...] comprehensive care is inherent in the nurses' doing [...]. (N. 1)

For nurses interviewed who use/used TT, comprehensive care is to transcend visible needs of the physical body, it is to care considering all human dimensions, in the singularity of each being. In order to have this care, it is necessary to understand being as a comprehensive part of the universe and that it is continuously interacting with the environment, influencing and being influenced each other in a cooperation process. It is to be clear about what people understand by health, in what context they are inserted and, from that, offer possibilities that aim at the quality of life within what is really important for them.

It is noticing the physical, emotional and spiritual energy aspects. So, comprehensive care is being aware of these issues, a person who is sad, sick or happy will have an issue of energy with them, an emotional with them, a physiological issue as well. (N. 2)

Taking care of being in the world, i.e., knowing and understanding the world of the subjects, and from there offer possibilities to 
promote quality of life, prevention of diseases and injuries, palliative care and healing through education, biopsychosocio-spiritual guidance, welcoming, understanding, knowledge, love, empathy, active listening, appropriate and efficient interventions. (N. 3)

This is my worldview, very much related to the ecosystem view. It is part of a system, with vulnerabilities and so on [...] so this web of the relationship between the environment and individuals and with the changes in which the planet earth has been going through even the human issues of destruction, the sense of the environment and the changes we made [...] my view is that of individuals with their energy issue with the external environment [...]. (N. 4)

As there is more than one meaning for the word "comprehensive" in the context worked on, it may happen that professionals diverge in their conduct when aiming to perform care in this perspective. This means that care is offered in different ways. Study participants understand that, when using TT, comprehensive care occurs through intuition, the understanding that the dimensions are intertwined, are interdependent and that the visible reported is not always the cause of imbalance in HEF. It is taking care considering that human beings are made up of dimensions that interact, make interconnections and are influencing and being influenced dynamically and continuously. It is to understand that there is an exchange of energies between those who care and those who are cared for and with the cosmos, aiming at a dynamic balance, in an ecosystemic view.

I think comprehensive is a polysemic word. It is a very broad concept, it can be understood as multidisciplinary work at different levels of attention to all the issues that we study in our profession. But specifically, at the time of TT, it is not possible to separate human beings into parts. When we face a person, who is going to be cared for with TT, our perceptions have to be of the whole. Sometimes the person may come complaining of pain in the arm, but we will assess the field as a whole, without devaluing your complaint, obviously. But we are not only focused on the biological, physiological dimension. In our conception, there is a being with dimensions that maybe in a simple way, we can say body, mind, energy or whatever you want to call energy fields, the mind and the physical field. There is no way to separate these dimensions at the time of TT. (N. 5)

From the views of interviewees, comprehensive care is a path that may not be achieved considering the reductionist view of the Western model. This influences the environment in which professionals are trained and perform their daily practices. For care to be carried out from the perspective of comprehensiveness, it understands that a change is needed in the vision of what human beings are, health and care.

I believe that the concept that we will never achieve this comprehensive care is somewhat utopian [...] this comprehensive care is related to how I see human beings, how I see the disease. In our Western context, I believe it is a utopia, very different from the Eastern view in relation to caring for human beings. Here we talk a lot about being bio-psycho-social as if the bio, the psycho and the social were separate things. So, I don't see that everything is separate, but interconnected, and comprehensive care for the very system we live in. This social economic model does not allow this to be achieved, this vision, this comprehensive care. Because it is something that we idealize, but for you to achieve this comprehensive care, you really need to mold yourself, change your view first, change your view of being a human being, of health, so that you can apply this comprehensive care [...] is to see the person in full [...]. (N. 6)

In the interviewees' statements based on TT, it is possible to perceive that, for comprehensive care to happen, it is necessary to understand the constitution of human beings as a whole, as well as the interconnection that this establishes and the influences on his way of living life. This must be understood and applied in caring for the other. It is necessary to see far beyond matter.

\section{[...] is to see the person in full [...]. (N. 7)}

[...] is to be able to perceive this interconnection, precisely between body, mind, spirit and emotions that influence the daily life, in the individual's way of life only a human being [...] it is necessary to consider the whole during the person's assessment because the things are interconnected; when we look at the matter, some things are not perceived [...]. (N. 8)

For the interviewees, comprehensive care considers what is really significant for the person, within their life values. It is listening and understanding what makes sense to the life of the person being cared for.

[...] it's perfect. You have to know that person, that individual fully; preferably, you have to understand a little their life context and job insertion, so you can get close to this person and talk, make a diagnosis of what he needs at that moment [...] it is comprehensive care if you know that person well [...] to really know what you can do, how you can help, how you can work with him or her, what you can do and what you cannot do [...] is to respect the other [...] we respect individuals, their beliefs, their desires, and in the middle of this whole context you put yourself and then we have a nice conversation and both learn from each other. (N. 9)

It is taking care using sensitivity and respect. It is to understand that care happens at the same time for professionals and persons, and in the encounter with the other, there is interaction and mutual influences. It is to understand that, based on this cooperation, there is a possibility of a dynamic balance.

[...] it is not caring how you would like to be cared for, but how the other person would like to be cared for, it is fundamental and extremely important to really question what makes the most sense for the person who is within the care environment [...] is to take care of everyone with simple gestures. (N. 10)

Perform sensitive and welcoming listening, seek to provide guidance, reflections and care according to the information and complaints provided and perceptions obtained by observing the verbal and non-verbal. (N. 11)

\section{DISCUSSION}

Care is a practice inherent to human beings; however, when linked to the actions of health professionals, it needs to be carried out considering the human complexity, as well as the context 
in which it is inserted and the connections and interrelations it establishes, as they are the ones that will influence the way of being, thinking, act and feel each one ${ }^{(13)}$.

Therefore, it is necessary to use references that enable the understanding of the ecosystem that the human being finds. Studies in nursing have been based on the ecosystem referential, as this goes beyond care based only on the biological dimension of human beings, considering, in addition to this, the socio-cultural, environmental and spiritual dimensions, as well as interactions that are established between them ${ }^{(14)}$; thus, it is possible to develop comprehensive care.

TT is a technique that balances the energy field, providing the harmonization of human dimensions. It is possible to awaken sensations, emotions and feelings, such as well-being, tranquility, self-knowledge, strengthening of bonds, reflections about choices to be made, the real meaning of life, among others, since this is a subjective process. In this regard, it is understood participants' perspectives' of comprehensiveness, from their experiences in TT use and discussed based on the ecosystem referential, theoretical support of the present study ${ }^{(15)}$.

Participants understand that comprehensive care is inherent to nurses and is already intrinsic in their actions, considering the philosophical theoretical bases of nursing that aim at the comprehensiveness of being. A research carried out with seven professors from an Undergraduate Nursing Course of a Higher Education Institution in Rio Grande do Sul, which aimed to understand how teachers perceived the comprehensive care approach in teaching-learning, found similar results, as participants reported that this care must be in the essence of nurses ${ }^{(16)}$.

In this construct, we highlight a study that aimed to present an analytical reflection on nursing care, in the current health setting, according to the essence of Martin Heidegger's care. The authors argue that, although nursing has care as its basis, sometimes it is observed to be performed automatically, mechanically, disregarding the real sense of care ${ }^{(17)}$. This thinking was observed in the speech of one of the interviewees, because, for him, comprehensive care is a path that may not be achieved considering the reductionist view of the Western model. This influences the environment in which professionals are trained and perform their daily practices. For care to be carried out from the perspective of comprehensiveness, a change is needed in the vision of what it is to be human, health and care. Still, it is emphasized that TT allows this broadening of look regarding the referred concepts.

In this perspective, a documentary study based on official documents from the Ministry of Health aimed to identify the elements capable of promoting comprehensiveness and humanization in the management of nursing care in Intensive Care Units, with an ecosystemic focus. Such study corroborates results found in the present research, because it addresses the need for innovation in the health work process, considering that the biomedical model is not sufficient to understand the totality of the dimensions that make up human beings as well as environment interaction ${ }^{(14)}$. Thus, it is pointed out that seeing human beings in a systemic conception is a way to contemplate the development of comprehensive care.

Considering the historical context of nursing, in which it was viewed as a subordinate profession to a science with its own references, it is known that there was a significant advance ${ }^{(18)}$; however, it is understood that, there are still many challenges to be overcome in comprehensive care practice, as it is necessary that these professionals insert it into their being and doing ${ }^{(3)}$.

According to the nurses interviewed, comprehensive care is to be able to go beyond the visible needs, just the physical body, it is to take care considering all human dimensions in their singularity. In order to have this care, it is necessary to understand being as part of the universe and that it is continuously interacting with the environment, influencing and being influenced each other in a cooperation process. It means being clear about what people mean by health, in what context it is inserted, and, from that, offering possibilities that aim at quality of life within what is important to them.

This thinking is in line with what was discussed in a reflection study in which the authors refer that it is necessary to know the other within their needs, i.e., listen to them, go beyond punctual assistance. It is necessary to know the human essence of those who seek care and need it constantly ${ }^{(19)}$.

Comprehensive care is based on the ecosystem reference, since human beings and their dimensions (intrinsic to it) are considered as part of an ecosystem formed by biotic (with life) and abiotic (without life) elements; all are interconnected, are interdependent and influence each other. From this perspective, it is understood that comprehensive care can be obtained by the dynamic balance between all elements belonging to the ecosystem, enabling human beings to have comprehensive health and conditions for maintenance of life ${ }^{(4,16)}$.

Nurses, when performing care through TT from an ecosystem perspective, are reporting to human beings in their entirety, as it broadens their view, which makes it possible to understand the environmental, physical, mental, spiritual relationships, among others ${ }^{(4,13-14,20)}$. From this point of view, it is understood that, through comprehensive care it is possible to emerge new bifurcations in nursing practice, given the fluctuations that this makes possible, because sometimes the practice is observed being carried out in a model focused on disease and in the professional ${ }^{(3,13)}$.

In the interviewees' statements, it is possible to realize that, for comprehensive care to happen, it is necessary to understand the constitution of human beings in their entirety, as well as the interconnection that it establishes and the influences on their way of living life. This must be understood and applied in caring for the other. It is necessary to see far beyond matter. One must consider what is really meaningful to the person, within their life values. One must listen and understand what makes sense to the life of the person being cared for. Care must be taken using sensitivity and respect, understanding that care happens at the same time for professional and person, and in the encounter with the other, there are interactions and mutual influences. It must be understood that, based on this cooperation, there is a possibility of a dynamic balance.

Therefore, it is understood that human beings are an interconnected and interconnected energy web, supported by the subtle energy systems that intertwine vital force and body. They are influenced, and cell growth patterns are affected positively or negatively, resulting in health and disease ${ }^{(21)}$.

For the nurses participating in the study, as there is more than one meaning for the word "comprehensive" in the context worked 
on, it may happen that professionals diverge in their conduct when aiming to provide care in this perspective. This means that care is offered in different ways; therefore, it is necessary to have a philosophical theoretical framework. One of the participants refers to care performed using TT as a possibility to achieve comprehensiveness.

When care happens associated with TT, intuition is used and it is understood that the dimensions are intertwined, are interdependent and that the visible reported is not always the cause of the imbalance in the energy field. It is taking care considering that human beings are made up of dimensions that interact, make interconnections and are influencing and being influenced continuously. It is to understand that there is an exchange of energies between those who care and those who are cared for and with the cosmos, aiming at a dynamic balance and that the systems and subsystems are in a process of cooperation.

In this regard, a study that aimed to analyze TT use by nursing addressed that, through this technique, care is performed highlighting the values that constitute human beings in their uniqueness $^{(8)}$. The present study also demonstrates the need to address the theme in the training setting, sensitizing future professionals to the importance and relevance of it in the context of health in the search for comprehensive care for human beings in nursing.

\section{Study limitations}

The limitations refer to the scarcity of research on the understanding of comprehensive care by nurses who work using TT. Another limitation is the small number of nursing professionals who use and disseminate work on the theme.

\section{Contributions to nursing}

The main contribution is to socialize the perception of nurses who work with TT about comprehensive care. Through this, it is possible to share the knowledge of the technique that is still little discussed and used in nursing. Also, the ecosystem framework, which guided the discussion, due to the possibility of, through it, visualizing human beings in their multidimensionality as well as the interactions and influences between the elements that constitute it, the environment and the cosmos itself.

\section{FINAL CONSIDERATIONS}

The results allowed to describe nurses' perceptions about comprehensive care for human beings considering their experiences/ studies with TT. They discussed the theme polysemically, as they understand comprehensive care as something inherent to nurses and that is intrinsic in their being and doing, how to go beyond visible needs and take care considering all human dimensions considering that the dimensions interact, making interconnections and influencing while being influenced. It is considered what is really meaningful to the person, within their life values.

It is necessary to understand that care actions focusing only on the biological dimension are still considered barriers to be overcome in different contexts, due to the reductionist view of the Western model. However, it should be noted that TT was mentioned as a possibility to care for human beings in their entirety.

It is considered that the objective of the study was achieved; however, it is understood the need for further research that advances this knowledge and uses the ecosystem framework, so that it provides innovations in nursing professional practice in different contexts.

\section{REFERENCES}

1. Rangel RF, Backes DS, Pimpão FD, Costenaro RGS, Martins ESR, Diefenbach GDF. Concepções de Docentes de Enfermagem Sobre Integralidade. Rev Rene [Internet]. 2012 [cited 2018 Sep 15];13(3):514-21. Available from: http://www.periodicos.ufc.br/rene/article/view/3969/3136.pdf

2. Rangel RF, Backes DS, Ilha S, Siqueira HCH, Martins FDP, Zamberlan C. Cuidado integral: significados para docentes e discentes de enfermagem. Rev Rene [Internet]. 2017 [cited 2018 Sep 15]; 18(1):43-50. Available from: http://www.periodicos.ufc.br/rene/article/viewFile/18866/29599.pdf

3. Assis MMA, Nascimento MAA, Pereira MJB, Cerqueira EM. Comprehensive health care: dilemmas and challenges in nursing. Rev Bras Enferm [Internet]. 2015 [cited 2018 Sep 16];68(2):333-8 Available from: http://www.scielo.br/pdf/reben/v68n2/en_0034-7167-reben-68-02-0333.pdf

4. Siqueira HCH, Thurow MRB, Paula SF, Zamberlan C, Medeiros AC, Cecagno D, et al. A saúde do ser humano na perspectiva ecossistêmica. Rev Enferm UFPE [Internet]. 2018 [cited 2019 Jan 30];12(2):559-64. Available from: https://periodicos.ufpe.br/revistas/revistaenfermagem/article/ viewFile/25069/27888

5. Ministério da Saúde (BR). Secretaria de Atenção à Saúde. Departamento de Atenção Básica. Política Nacional de Práticas Integrativas e Complementares no SUS - PNPIC-SUS[Internet]. Brasília, (DF): Ministério da Saúde; 2006 [cited 2018 Sep 15]. Available from: http://bvsms. saude.gov.br/bvs/publicacoes/pnpic.pdf

6. Telesi Jr ET. Práticas integrativas e complementares em saúde, uma nova eficácia para o SUS. Estud. Av [Internet]. 2016 [cited 2018 Sep 14];30(86):99-112. doi: 10.1590/S0103-40142016.00100007

7. Sá AC. Toque Terapêutico, uma novidade chega ao Brasil. Rev Nurs [Internet]. 2018 [cited 2018 Sep 17];21(236):2010-12 Available from: http://www.revistanursing.com.br/revistas/236-Janeiro2018/entrevistas.pdf

8. Sousa RM, Guimarães CM. Aplicação do toque terapêutico na assistência complementar em enfermagem. Estudos [Internet]. 2014 [cited 2018 Sep 17];41(Esp):151-63. Available from: http://seer.pucgoias.edu.br/index.php/estudos/article/view/3815/2179.pdf

9. Ministério da Saúde (BR). Portaria 702, de 21 de março de 2018. Altera a Portaria de Consolidação n 2/GM/MS, de 28 de setembro de 2017, para incluir novas práticas na Política Nacional de Práticas Integrativas e Complementares - PNPIC [Internet]. Brasília, (DF): Ministério da Saúde 2018 [cited 2018 Sep 17] Available from: http://bvsms.saude.gov.br/bvs/saudelegis/gm/2018/prt0702_22_03_2018.html 
10. Conselho Nacional de Saúde (BR). Diretrizes e normas regulamentadoras de pesquisa em seres humanos. Resolução n 466 , de 12 de dezembro de 2012 [Internet]. Brasília, (DF): Ministério da Saúde 2012 [cited 2018 Sep 14] Available from: http://bvsms.saude.gov.br/bvs/ saudelegis/cns/2013/res0466_12_12_2012.html

11. Capra F, Luisi PL. A visão sistêmica da vida: uma concepção unificada e suas implicações filosóficas, políticas, sociais e econômicos. São Paulo: Cultrix; 2014.

12. Moraes R, Galiazzi MC. Análise textual discursiva. 2a ed. ljuí: Editora Unijuí, 2011.

13. Zamberlan C, Medeiros AC, Dei Svaldil J, Siqueira HCH. Ambiente, saúde e enfermagem no contexto ecossistêmico. Rev Bras Enferm [Internet] 2013 [cited 2018 Set 15];66(4):603-6 Available from: http://www.scielo.br/pdf/reben/v66n4/v66n4a21.pdf

14. Medeiros AC, Siqueira HCH, Zamberlan C, Cecagno D, Nunes SS, Thurow MRB. Comprehensiveness and humanization of nursing care management in the Intensive Care Unit. Rev Esc Enferm USP. 2016;50(5):816-2. doi: 10.1590/s0080-623420160000600015

15. Rangel RF, Medeiros AC, Oliveira ACC, Rodrigues ST, Scarton J, Siqueira HCH. Effects of therapeutic touch on integral care to humans in the light of Ecosystem Thinking. Res, Soc Develop [Internet]. 2020 [cited 2020 Jun 23];9(4):e176942421. Available from: https://rsd.unifei.edu.br/ index.php/rsd/article/view/2421/2730

16. Rangel RF, Costenaro RGS, Ilha S, Zamberlan C, Siqueira HCH, Backes DS. Training for integral care: perception of nursing teachers and students. Rev Pesqui: Cuid Fundam[Internet] 2017 [cited 2018 Sep 15];9(2):488-94 Available from: http://seer.unirio.br/index.php/ cuidadofundamental/article/view/5450/pdf

17. Santos AGS, Monteiro CFS, Nunes BMVT, Benício CDAV, Nogueira LT. O cuidado em enfermagem analisado segundo a essência do cuidado de Martin Heidegger. Rev Cubana Enferm [Internet]. 2017 [cited 2018 Sep 15];33(3):1-11 Available from: http://www.ufj.br/pgenfermagem/ files/2018/04/O-cuidado-em-enfermagem-analisado-segundo-a-ess\%C3\%AAncia-do-cuidado-de-Martin.pdf

18. Donoso MTV, Donoso MD. O cuidado e a enfermagem em um contexto histórico. Rev Enferm UFJF [Internet]. 2016 [cited 2018 Sep 16];2(1):51-5 Available from: https://enfermagem.ufjf.emnuvens.com.br/enfermagem/article/view/71/40

19. Petersen CB, Lima RAG, Boemer MR, Rocha SMM. Health needs and nursing care. Rev Bras Enferm. 2016;69(6):1168-71. doi: 10.1590/0034-7167-2016-0128

20. Severo DF, Siqueira $\mathrm{HCH}$. Interconnection between the history of Brazilian nursing education and the ecosystem thoughts. Rev Bras Enferm. 2013;66(2):278-81. doi: 10.1590/S0034-71672013000200019

21. Gerber R. Medicina vibracional: uma medicina para o futuro. 9a ed. São Paulo: Cultrix, 2007 